\title{
Screening and kinetics of glutaminase and glutamate decarboxylase producing lactic acid bacteria from fermented Thai foods
}

\author{
Sasimar WORAHARN ${ }^{1}$, Narissara LAILERD², Bhagavathi Sundaram SIVAMARUTHI ${ }^{1}$, \\ Wiwat WANGCHAROEN ${ }^{3}$, Sophon SIRISATTHA ${ }^{4}$, Chaiyavat CHAIYASUT ${ }^{1 *}$
}

\begin{abstract}
L-glutaminase and glutamic acid decarboxylase (GAD) catalyzes the hydrolysis of L-glutamine and glutamate, respectively. L-glutaminase widely used in cancer therapy along with a combination of other enzymes and most importantly these enzymes were used in food industries, as a major catalyst of bioconversion. The current investigation was aimed to screen and select L-glutaminase, and GAD producing lactic acid bacteria (LAB). A total of $338 \mathrm{LAB}$ were isolated from fermented meat, fermented fish, fermented soya bean, fermented vegetables and fruits. Among 338 isolates, 22 and $237 \mathrm{LAB}$ has been found to be positive for L-glutaminase and GAD, respectively. We found that 30 days of incubation at $35^{\circ} \mathrm{C}$ and $\mathrm{pH} 6.0$ was the optimum condition for glutaminase activity by G507/1. G254/2 was found to be the best for GAD activity with the optimum condition of $\mathrm{pH}$ 6.5 , temperature $40^{\circ} \mathrm{C}$ and ten days of incubation. These LAB strains, G507/1 and G254/2, were identified as close relative of Lactobacillus brevis ATCC 14869 and Lactobacillus fermentum NBRC 3956, respectively by 16S rRNA sequencing. Further, improvements in up-stream of the fermentation process with these LAB strains are currently under development.
\end{abstract}

Keywords: L-glutaminase; glutamic acid decarboxylase; lactic acid bacteria and 16S rRNA sequencing.

Practical Application: LABs based safe starter culture for the fermentation of mushroom to produce high GABA.

\section{Introduction}

Glutaminase distributed in all the microbes like bacteria, yeast and fungi, and they were reported to produce notable amount of glutaminase (Nandakumar et al., 2003). This enzyme widely used in food industries for the enzymatic degradation of proteins, which present in the raw materials. More specifically, flavor of the fermented soy sauce is due to glutamic acid produced by glutaminase. There are many numbers of glutaminase reported from different microbial sources with a wide range of fermentation conditions as summarized by Nandakumar et al. (2003). More specifically, they differ in molecular weight, optimum $\mathrm{pH}$ and substrate specificity. Several glutaminases were reported to have both an optimal and stable temperature of $\sim 40-50{ }^{\circ} \mathrm{C}$. Some previous studies have reported about the temperature stability and activity of several glutaminases (Prusiner et al., 1976; Moriguchi et al., 1994; Koibuchi et al., 2000). Glutaminases from Aspergillus oryzae, Micrococcus luteus K-3 and Bacillus subtilis are known for its high-salt tolerance capacity (Yano et al., 1988; Moriguchi et al., 1994; Madern et al., 2000; Kennedy et al., 2001).

The transfer of L-glutamic acid to $\gamma$-aminobutyric acid (GABA) and carbon dioxide can be mediated by the enzyme called glutamic acid decarboxylase (GAD) with pyridoxal as cofactor (Krnjević, 1974). GABA is a well-known inhibitory neurotransmitter, and its deficiency leads to Parkinson's disease,
Huntington's chorea and cognitive impairment. GABA also plays a role in controlling blood pressure, cholesterol level and has anti-diabetic property (Shimada et al., 2009; Soltani et al., 2011). As like glutaminase, GAD also presents diversely, and they mostly derived from microbial sources ranging from bacterias, yeasts and molds (Kato et al., 2002; Yang et al., 2008a, b). FDA and WHO have approved the use of these enzymes for food fermentation (Food and Agricultural Organization \& World Health Organization, 1987).

$\mathrm{LAB}$ genus is known as starter cultures in fermented food and beverage industries. LAB is usually known as safe (generally recognized as safe; GRAS) (Bovo et al., 2014). Fermented foods are a good source for LAB isolation. LAB isolated from fermented food was considerate as safe and suitable for food and beverage applications (Bovo et al., 2014; Fraga Cotelo et al., 2013; Pérez-Chabela et al., 2008). LABs are recognized probiotic for human usage particularly in fermented food production (Leroy et al., 2006; Yerlikaya, 2014). Lactobacillus casei, Lactobacillus paracasei subsp. paracasei, Lactobacillus sanfranciscensis, Lactobacillus reuteri, Lactobacillus lactis subsp. cremoris are reported to produce glutaminase (Kieronczyk et al., 2001; Weingand-Ziadé et al., 2003). Thongsanit et al. (2009) isolated Leuconostoc citreum from Thai fermented pork sausage with glutaminase activity. The previous reports have suggested 
that Listeria monocytogenes, Escherichia coli and Lactococcus lactis can produce GAD (Lin et al., 1995; Sanders et al., 1998; Cotter et al., 2001). GAD of Lactobacillus brevis and L. paracase $i$ are biochemically well characterized (Hiraga et al., 2008; Komatsuzaki et al., 2008). L. brevis OPK-3 was isolated from traditional fermented food of Korea with the ability of producing $84.292 \mathrm{mg} / \mathrm{L} / \mathrm{h}$ of $\gamma$-aminobutyric acid (Park \& Oh, 2006). Komatsuzaki et al. (2005) have reported the ability of L. paracasei to produce GAD isolated from traditional fermented foods. A study by Yokoyama et al. (2002) explains the use of L. brevis IFO-12005 for the production of $\gamma$-aminobutyric acid from the residue of alcohol distillery. Recently, a study has reported that $L$. reuteri $100-23$ play a role in acid resistance during fermentation owing to the production of GAD (Su et al., 2011).

There have been no detailed reports regarding the production and characterization of glutaminase and GAD from lactic acid bacteria isolated from Thai fermented food. Thus, this study has focused on the isolation and identification of glutaminase and GAD-producing LAB from various Thai fermented foods and subsequently characterization of glutaminase and GAD activity.

\section{Materials and methods}

\subsection{Isolation of lactic acid bacteria (LAB)}

Total LABs were isolated from fermented foods such as fermented meat, fish, soya bean, vegetables and fruits, which were aseptically collected from different areas of Thailand. Bacterial isolation was carried out by serial dilution and pour plate method. Briefly, $5 \%$ of samples were prepared in saline solution $(0.90 \%(\mathrm{w} / \mathrm{v}) \mathrm{NaCl})$ and used as a stock. Then, the sample was serially diluted in saline and plated on Man Rogosa Sharpe agar (MRS agar, Labscan, Cat. No. LS 1168) incorporated with $0.005 \%$ of bromocresol purple (Fisher scientific, Cat No. $\mathrm{B} / 4330 / 44)$ by pour plate method. The plates were incubated at $37{ }^{\circ} \mathrm{C}$ for $24-48 \mathrm{~h}$. After incubation, colonies with yellow pigmentation were considered as LAB and selected for further analysis. Pure cultures of the selected LABs were stored at $-20^{\circ} \mathrm{C}$ with 40\% glycerol (Balagurunathan et al., 2010; Aramide et al., 2009; Bertazzoni Minelli et al., 2004).

\subsection{Screening for glutaminase activity}

LABs were cultured in MRS broth with $1.5 \%(\mathrm{w} / \mathrm{v})$ of L-glutamine (Sigma, Cat. No. 49419) at $37{ }^{\circ} \mathrm{C}$ for $24 \mathrm{~h}$. Then, the cells were harvested by centrifugation at $6000 \mathrm{rpm}$ for $5 \mathrm{~min}$, and the supernatants were subjected to screening of extracellular glutaminase activity. Bacterial pellets were further washed with $0.85 \%(\mathrm{w} / \mathrm{v})$ of $\mathrm{NaCl}$ and dissolved in the same solution. Followed by, the bacterial suspensions were divided into two equal volumes, and one part was subjected to the analysis of cell-wall-associated glutaminase. Rest of the cell suspensions were subjected to ultrasonication process, after the freeze-thaw treatment by an alternative incubation at $-20^{\circ} \mathrm{C}$ and RT for $30 \mathrm{~min}$, at $120 \%$ of ultrasound power for $20 \mathrm{~min}$ using ultra-sonicator (Elma, Model no.D-78224 Singen/Htw) for the determination of intracellular glutaminase activity. The activity of glutaminase was measured by estimating the amount of $\mathrm{NH}_{3}$ liberated from L-glutamine (Katikala et al., 2009). In brief, $500 \mu \mathrm{l}$ of $0.04 \mathrm{M}$ of L-glutamine prepared in $0.1 \mathrm{M}$ phosphate buffer $\mathrm{pH}$ 7.0 was mixed with $500 \mu \mathrm{l}$ of samples and incubated at $37^{\circ} \mathrm{C}$ for $30 \mathrm{~min}$. After incubation, $0.5 \mathrm{ml}$ of $1.5 \mathrm{M}$ of trichloroacetic acid (TCA) was added to stop the enzymatic reaction. Then equal volume of Nessler's reagent (Merck. Cat. No.109028) was added and incubated at RT until the appearance of yellow color (5-15 min). Then the samples were centrifuged at $5000 \mathrm{rpm}$ for $3 \mathrm{~min}$ and the absorbance of the supernatant was measured at $450 \mathrm{~nm}$ using a multimode detector (Beckman Coulter, Model. No. DTX 880). TCA solution mixed with L-glutamine and Nessler's reagent served as blank. Ammonia content was calculated by using $\mathrm{NH}_{4} \mathrm{SO}_{4}$ as standard. One international unit of glutaminase was defined as the amount of enzyme that liberates one micromole of ammonia under optimum conditions. The enzyme yield was expressed as unit $/ \mathrm{ml}$ or as specific activity (U/mg protein).

\subsection{GAD activity assay}

All strains were tested by rapid colorimetric assay using bromocresol green as $\mathrm{pH}$ indicator for GAD activity (Cotter et al., 2001; Olier et al., 2004). Overnight culture of LABs were centrifuged at $8000 \mathrm{rpm}$ for $10 \mathrm{~min}$ and the bacterial pellet was dissolved in $500 \mu \mathrm{l}$ of test solution, consist of $1 \mathrm{~g}$ of L-glutamic acid (Sigma), $300 \mu$ of Triton X-100(Sigma), $90 \mathrm{~g} \mathrm{NaCl}$ (Merck), and $0.05 \mathrm{~g}$ bromocresol green (Labchem) dissolved in 1 liter of water, after washing with $0.90 \%(w / v)$ of $\mathrm{NaCl}$. The development of green or blue color was considered as low or high activity for GAD, respectively. Three independent experiments were carried out for each strain tested.

\subsection{Effect of $\mathrm{pH}$ and temperature on LABs growth and enzyme kinetics}

Selected positive LABs were cultured in modified medium for respective enzymes. Then, these cultures were re-inoculated in the medium containing of $10 \%(\mathrm{w} / \mathrm{v})$ of cane sugar (CS) and $1.5 \%(\mathrm{w} / \mathrm{v})$ L-glutamine with range of $\mathrm{pH}$ from 6-8, followed by the medium was incubated at different temperatures like $30,35,40^{\circ} \mathrm{C}$ for 30 days. Glutaminase activity was denoted as $\mathrm{U} / \mathrm{ml}$. GAD-producing LABs were inoculated in the medium containing $10 \%(\mathrm{w} / \mathrm{v})$ CS with $0.1 \%(\mathrm{w} / \mathrm{v})$ of L-glutamic acid with $\mathrm{pH}$ range of $4.5,5.5$ and 6.5 and incubated at different temperatures like $30,35,40{ }^{\circ} \mathrm{C}$ for 30 days. Level of GABA and L-glutamic acid was measured by HPLC and growth kinetic of the LABs were assessed by OD at $600 \mathrm{~nm}$.

\subsection{HPLC for GABA and L-glutamic acid}

GABA and L-glutamic acid content in the culture were determined by HPLC analysis. Briefly, $1 \mathrm{ml}$ of culture was centrifuged at 6,000 $\mathrm{rpm}$ for $10 \mathrm{~min}$ and supernatant was collected for derivatization with PITC (phenyl isothiocyanate). Analysis was performed using HPLC equipped with a C18 column $(4.6 \times 250 \mathrm{~mm}, 5 \mu \mathrm{m})$. The elution solvent system consists of $70 \mathrm{mM}$ of sodium acetate $\mathrm{pH} 5.8$ (A) and 55\% (v/v) of acetonitrile (B).UV detector at $254 \mathrm{~nm}$ was used. The flow 
rate was adjusted as $1 \mathrm{ml} / \mathrm{min}$ and the sample injection volume was $20 \mu \mathrm{l}$. L-glutamic acid and GABA were served as standards.

\subsection{Molecular identification of LAB isolates}

Genomic DNA of the LAB was isolated by standard procedure (Sambrook \& Russell, 2001) and 16S rRNA coding gene was amplified using gene specific primers (Forward primer 5'-AGAGTTTGATCCTGGCTCAG-3'; Reverse primer 5'-GGTTACCTTGTTACGACTT-3'). The amplified DNA fragment was subjected to sequencing by Sanger's method. Sequences were analyzed, and taxonomic strain identification was performed by comparing the sequences of each strain with those reported in EZTaxon (http://www.ezbiocloud.net/ eztaxon/) database. Phylogenetic for LABs were constructed by the neighbor-joining method (Kim et al., 2012). The topologies of trees analyzed by bootstrap analysis of the sequence with MEGA 6 software based on 100 random resembling.

\subsection{Statistical analysis}

All the experiments were performed in three independent repeats, and the values were plotted as Mean \pm SD.

\section{Results and discussion}

\subsection{LABs with glutaminase activity}

Total strains of 338 lactic acid bacteria (LAB) strains were isolated from various fermented foods as detailed (Supplementary Table 1). All the LABs were screened for glutaminase production as per the procedure stated in materials and methods section. Among 338 isolates, 22 LABs were capable of producing as glutaminase producers, and they were further analyzed for localization of the enzyme. About 3, 12, 7 strains were found to produces extracellular glutaminase, intracellular, cell-wall associated enzyme producers, respectively. Among these positives, 12 strains (4, 6 and 2 strains were attributed for the production of extracellular, intracellular and cell-wall associated enzymes, respectively) were selected as high scorer (Table 1) and both extracellular and cell-wall associated enzyme activity was observed in a LAB isolate denoted as G415/2. Strains G507/1 (2.88 $\pm 0.19 \mathrm{U} / \mathrm{mg}$ protein), G284/2 (6.07 $\pm 0.28 \mathrm{U} / \mathrm{mg}$ protein) and $\mathrm{G} 270 / 2(0.85 \pm 0.19 \mathrm{U} / \mathrm{mg}$ protein $)$ were found as best extra-cellular, intracellular and cell-wall associated enzyme producers, respectively. These results suggested that intracellular glutaminase producing LABs are more harbored in selected food sources than other strains. Moreover, these strains were reported for its highest enzyme production compared to others (Table 1),based on the enzyme producing ability, strains denoted as G507/1 (extracellular glutaminase producer) and G284/2 were selected for further analysis.

\subsection{Kinetics of growth and glutaminase production}

Selected two glutaminase producing strains were further kinetically analyzed to study the impact of $\mathrm{pH}$ and temperature on enzyme production. Glutaminase production was assessed at different temperatures $\left(30,35,40^{\circ} \mathrm{C}\right)$ and $\mathrm{pH}(6,7,8)$ as detailed in materials and methods section. Amount of enzyme production was denoted as $\mathrm{U} / \mathrm{mg}$ of protein. The results indicated that G507/1 produces highest amount of enzyme $\left(7.46 \mathrm{U} / \mathrm{mg}\right.$ of protein) than other strain at $35^{\circ} \mathrm{C}$ with the $\mathrm{pH}$ of 6.0 after 30 days of incubation and also this is the only strain that can produce, at least, trace amount of enzyme at all the tested conditions (Supplementary Table 2, Figure 1a). Growth rate of $\mathrm{G} 507 / 1$ at $35^{\circ} \mathrm{C}, \mathrm{pH} 6.0$ was also assessed for 30 days, and it was found to be a typical multiplication (Figure 1b). Previous study by Jeon et al. (2009) has reported that L. reuteri KCTC3594 produces the glutaminase with optimum activity at $40{ }^{\circ} \mathrm{C}$ and $\mathrm{pH} 7.5$; moreover, it shows $50 \%$ of activity at high salt concentration. Marine actinomycetes produce L-glutaminase with optimum activity at $27^{\circ} \mathrm{C}$ and $\mathrm{pH} 9.5$ after $96 \mathrm{~h}$ of incubation (Sivakumar et al., 2006).

These results suggested that optimum L-glutaminase activity is varied from $\mathrm{pH}$ 6.0-9.0 and temperature at $27-40{ }^{\circ} \mathrm{C}$ depends on the isolation source. The earlier study related to glutaminase producing bacteria from Thai food by Thongsanit et al. (2009) suggested that food isolate of Weisella cibaria can able to produce $0.0085 \mathrm{U} / \mathrm{mg}$ of enzyme whereas the present study have reported that LAB isolate can produce $7.46 \mathrm{U} / \mathrm{mg}$ of enzyme.

Table 1. Production of glutaminase producing by LAB strains and classification based on the nature of enzyme in habitation.

\begin{tabular}{|c|c|c|c|c|}
\hline \multirow{2}{*}{ S. No. } & \multirow{2}{*}{ Strains } & \multicolumn{3}{|c|}{ Specific activity of glutaminase (U/mg protein) } \\
\hline & & Extracellular enzyme & Intracellular enzyme & Cell-wall-associated enzyme \\
\hline 1 & G314/2 & ND & $1.37 \pm 0.30$ & ND \\
\hline 2 & G256/1 & ND & $2.78 \pm 0.20$ & ND \\
\hline 3 & G256/2 & ND & $4.35 \pm 0.25$ & ND \\
\hline 4 & G284/1 & ND & $3.67 \pm 0.17$ & ND \\
\hline 5 & G284/2 & ND & $6.07 \pm 0.28$ & ND \\
\hline 6 & G479/1 & $0.70 \pm 0.24$ & $\mathrm{ND}$ & ND \\
\hline 7 & G339/1 & $1.43 \pm 0.19$ & ND & ND \\
\hline 8 & G415/2 & $0.18 \pm 0.15$ & $\mathrm{ND}$ & $0.52 \pm 0.26$ \\
\hline 9 & G30/2 & ND & $\mathrm{ND}$ & $0.34 \pm 0.23$ \\
\hline 10 & G26/1 & ND & $3.02 \pm 0.18$ & ND \\
\hline 11 & G507/1 & $2.88 \pm 0.19$ & ND & ND \\
\hline 12 & G270/2 & $\mathrm{ND}$ & $\mathrm{ND}$ & $0.85 \pm 0.19$ \\
\hline
\end{tabular}

Values are represented as mean \pm SD of three experiments. (ND: Not detected). 


\subsection{Screening and kinetics of GAD activity}

All the isolated LABs (338) were screened for GAD activity as detailed in materials and methods section. A total of 17, 36 and 215 isolates were categorized as high, medium and low amount of GAD producers based on the color development during the screening test, respectively (Figure 2).

Previous studies have reported that bacterial pathogens could synthesize GAD with $\mathrm{pH}$ optima in the acid range, so they can function even if the internal $\mathrm{pH}$ is varied (Foster, 2001). Two isolates (G30/1 and G254/2) were selected for kinetic analysis, and the efficiency of the GAD was assessed by measuring the GABA production and residual glutamic acid in the medium (Supplementary Table 3 and 4). The isolate G254/2 produces a maximum amount of GABA $(12.73 \pm 1.0 \mathrm{mg} / \mathrm{ml})$ at $40{ }^{\circ} \mathrm{C}, \mathrm{pH}$ of 6.5 after ten days of incubation (Figure $3 \mathrm{a}$ ). The process was continued up to 30 days to study the consistency or enzyme activity, and the results indicated that increased incubation decreases the activity. When temperature and $\mathrm{pH}$ level is decreased GABA production also reduced. Therefore, GAD production by G254/2 depends on these two physical parameters (Figure 3a). Bacterial growth were assessed during optimum test condition and found to be normal (Figure 3b).
Another strain, G30/1, produced the maximum amount of GABA $(8.96 \pm 0.3 \mathrm{mg} / \mathrm{ml})$ at $35^{\circ} \mathrm{C}, \mathrm{pH}$ of 4.5 after 15 days of incubation. In this case, increase in $\mathrm{pH}$ and temperature affects the productivity (Supplementary Table 3 ).

Previous studies reported that L. paracasei, isolated from Japanese traditional fermented fish, can produce GABA at a concentration of 302 mM (Komatsuzaki et al., 2005), L. plantarum DW 12 produce about $4000 \mathrm{mg} / \mathrm{l}$ in a fermented red seaweed beverage system after 60 days of incubation (Ratanaburee et al., 2011). L. lactis (Lu et al., 2009; Siragusa et al., 2007), Lb. buchneri (Cho et al., 2007; Park \& Oh, 2006), Lb. delbrueckii subsp. bulgaricus (Siragusa et al., 2007), Bifidobacterium dentium (Barrett et al., 2012), and Streptococcus salivarius subsp. thermophilus (Yang et al., 2008b) are reported to produce GAD with different efficiency and optimum conditions.

The current study has identified two GAD producing strains that are varied in their ability to produce GABA and optimum physical parameters like temperature and $\mathrm{pH}$. The residual glutamic acid analysis also supported the above said statements (Supplementary Table 4). (a)

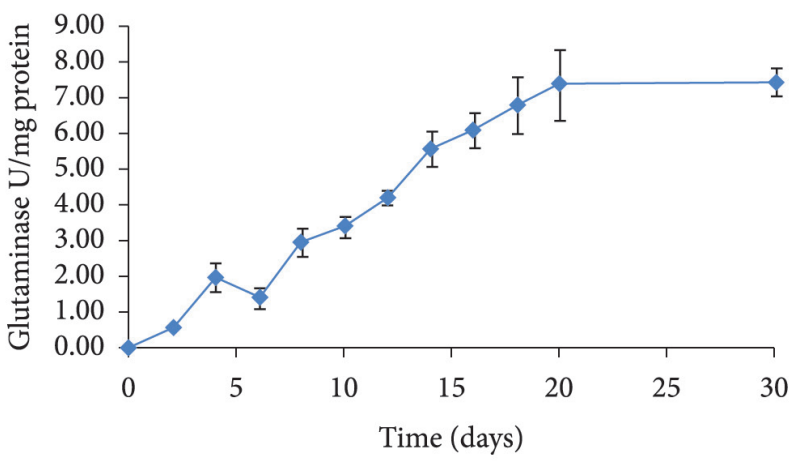

(b)

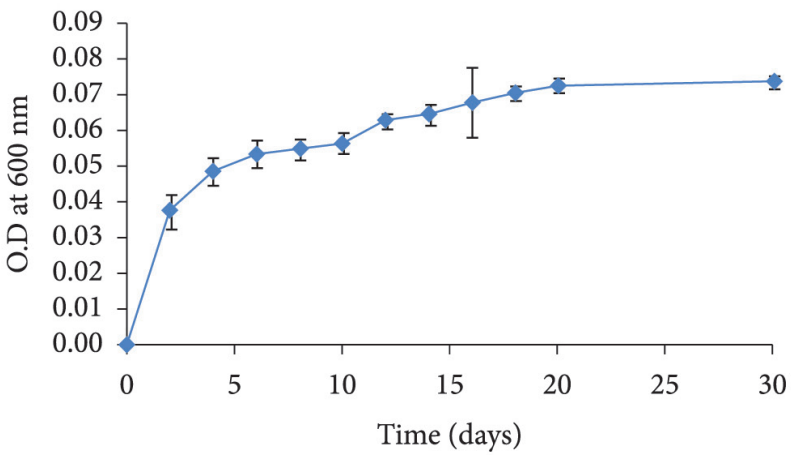

Figure 1. Kinetics of glutaminase production (a) and growth pattern (b) of G507/1 in optimum condition (Temperate at $35^{\circ} \mathrm{C}$, $\mathrm{pH} 6.0,30$ days of incubation).

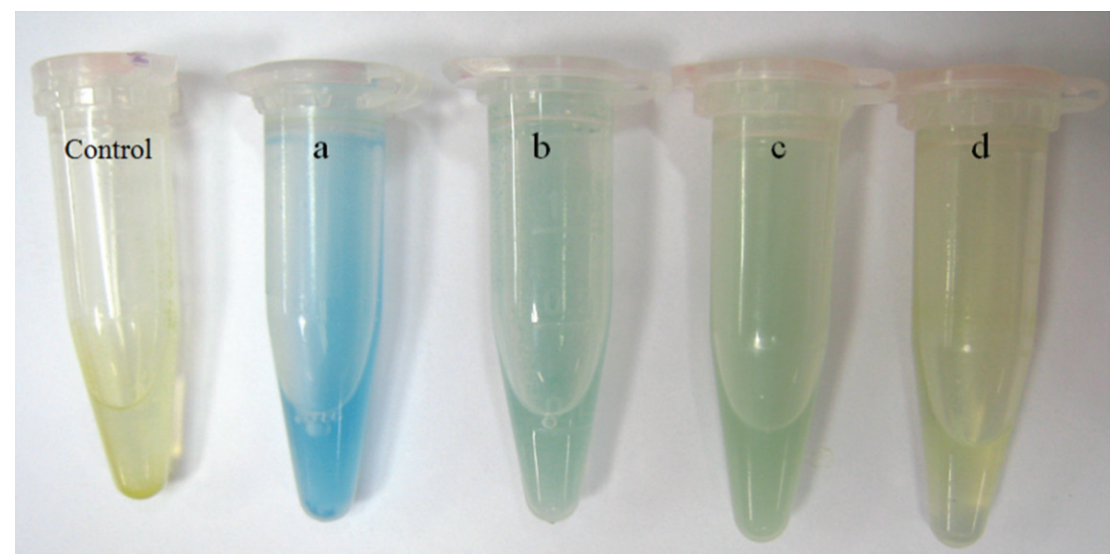

Figure 2. The representative picture shows high (a), medium (b) and low (c) level of GAD production during rapid colorimetric assay using bromocresol green as $\mathrm{pH}$ indicator for GAD activity. Medium control and negative results were denoted as control and (d), respectively. 


\subsection{Bacterial identification}

16s rRNA based molecular identification of bacterial strains was employed to identify the glutaminase producer-G507/1 and GAD producer-G254/2. Sequencing and phylogenetic tree were construed as explained in materials and methods. G507/1, which is a glutaminase-producing LAB was identified as Lactobacillus brevis ATCC 14869 (Accession number KI271266) with 99.86\% of 16s rRNA sequence similarity (Figure 4a). The strain G254/2, which is a GAD-producing LAB was identified as Lactobacillus fermentum NBRC 3956 (Accession number AP008937) with $99.86 \%$ of $16 \mathrm{~s}$ rRNA sequence similarity (Figure $4 \mathrm{~b}$ ). There is no detailed report about $L$. fermentum mediated GABA production. A previous report by Yokoyama et al. (2002) has enlightened the use of $L$. brevis for the production of $\gamma$ - aminobutyric acid from the residue of alcohol distillery.
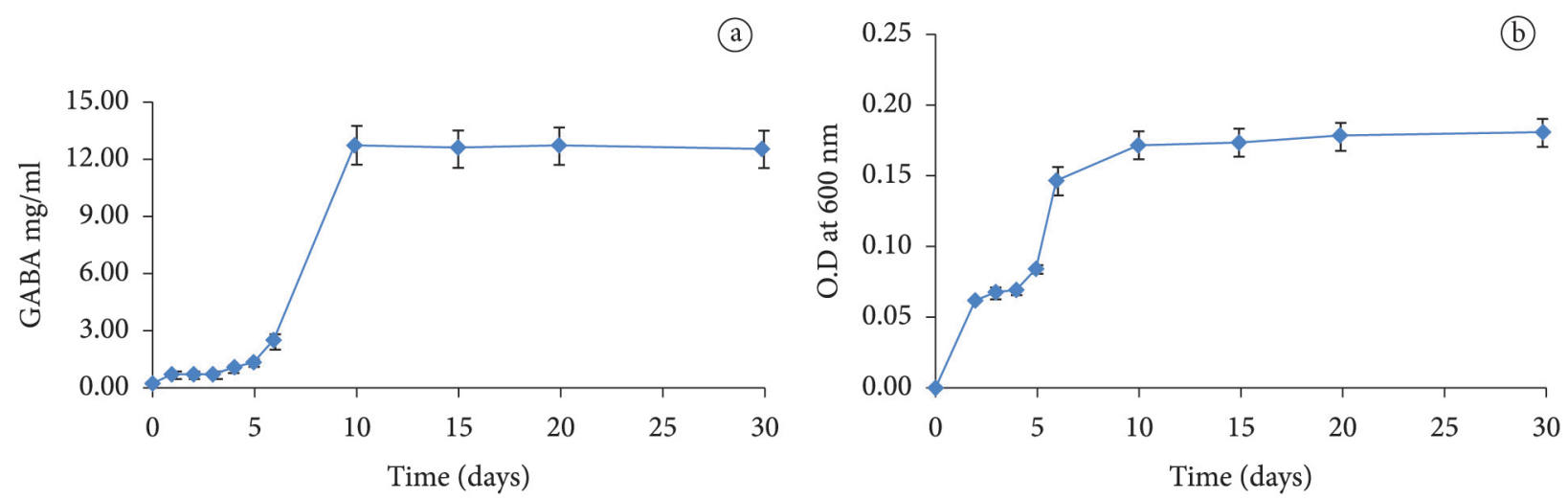

Figure 3. Kinetics of GABA production (a) and growth pattern (b) of G254/2 in optimum condition (Temperate at $40{ }^{\circ} \mathrm{C}$, $\mathrm{pH} 6.5,10$ days of incubation).

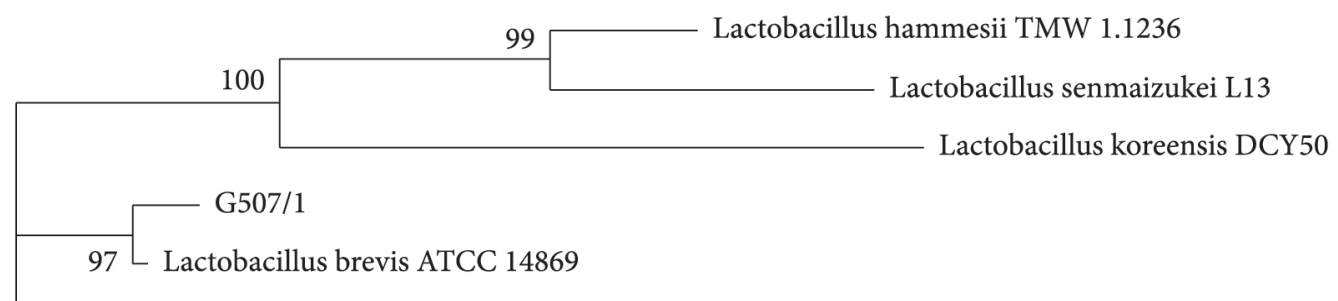

Lactobacillus spicheri LTH 5753

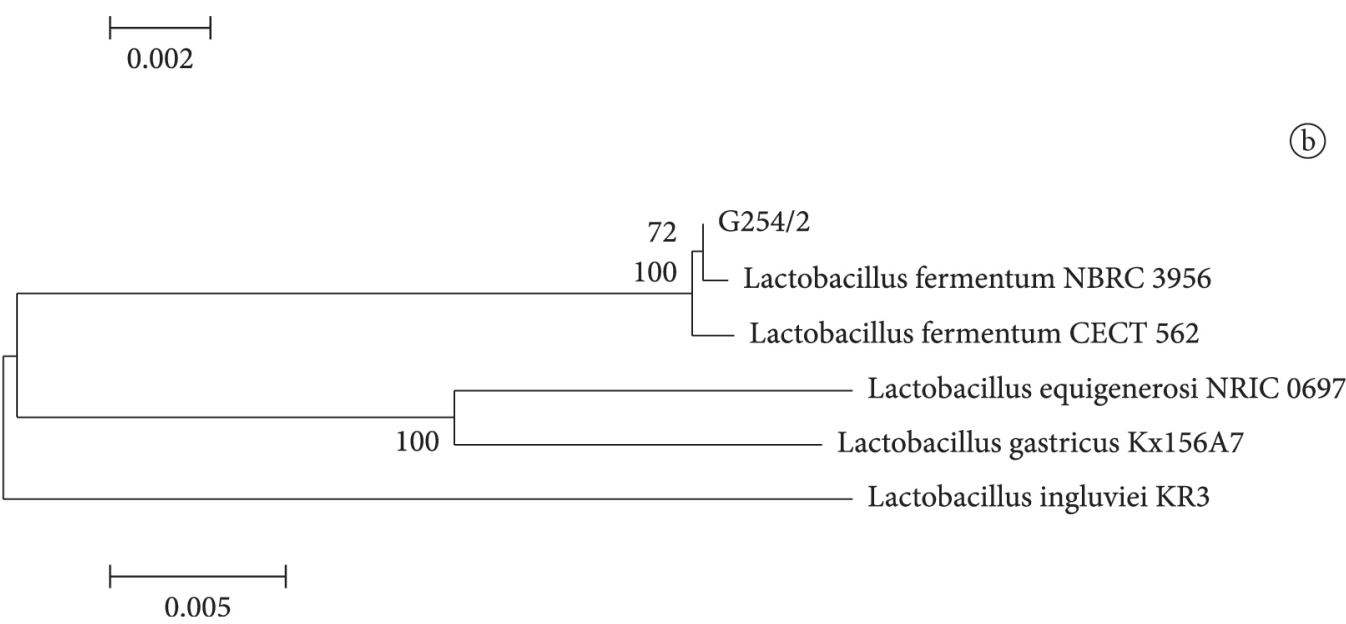

Figure 4. Phylogenetic representation of identified LABs (a) G507/1 displayed 99.86\% of similarity with Lactobacillus brevis ATCC 14869 (Accession number KI271266) and (b) G254/2 was identified as Lactobacillus fermentum NBRC 3956 (Accession number AP008937) with 99.86\% of similarity. 
A study has reported the cloning and expression of GAD from L. brevis OPK-3 in E. coli (Park \& Oh, 2007), but the enzyme was unstable. The GAD produced by L. brevis was biochemically well characterized previously (Hiraga et al., 2008). L. brevis PM17 was also reported for the GABA-producing ability (Siragusa et al., 2007).

\section{Conclusions}

The current investigation revealed that tested Thai fermented foods are rich in LABs with glutaminase and GAD producing capacity. Isolated L. brevis ATCC 14869 and L. fermentum NBRC 3956 produces relatively higher amount of glutaminase and GAD, respectively which can further used for fermentation processes as a safe starter. Further molecular characterization of these strains and other isolates will provide the comprehensive inspiration about use of these strains for the fermentation process in the future.

\section{Acknowledgments}

Authors thankfully acknowledge the Higher Education Commission, Thailand for the financial support through "Strategic Scholarships for Frontier Research Network for the Joint Ph.D. Program". The authors also gratefully acknowledge Chiang Mai University for the financial assistance.

\section{References}

Aramide, A. A., Abiose, S. H., \& Adeniran, A. H. (2009). Microbial evaluation of probiotic beverage from roselle extract. African Journal of Food Science, 1(12), 385-392.

Balagurunathan, R., Radhakrishnan, M., \& Somasundaram, S. T. (2010). L-glutaminase producing Actinomycetes from marine sediments selective isolation, semi quantitative assay and characterization of potential strain. Australian Journal of Basic and Applied Sciences, 4(5), 698-705.

Barrett, E., Ross, R. P., O’Toole, P. W., Fitzgerald, G. F., \& Stanton, C. (2012). $\gamma$-Aminobutyric acid production by culturable bacteria from the human intestine. Journal of Applied Microbiology, 113(2), 411-417. http://dx.doi.org/10.1111/j.1365-2672.2012.05344.x. PMid:22612585

Bertazzoni Minelli, E., Benini, A., Marzotto, M., Sbarbati, A., Ruzzenente, O., Ferrario, R., Hendriks, H., \& Dellaglio, F. (2004). Assessment of novel probiotic Lactobacillus casei strains for the production of functional dairy foods. International Dairy Journal, 14(8), 723-736. http://dx.doi.org/10.1016/j.idairyj.2004.01.007.

Bovo, F., Franco, L. T., Rosim, R. E., \& Oliveira, C. A. F. (2014). Ability of a Lactobacillus rhamnosus strain cultured in milk whey based medium to bind aflatoxin B1. Food Science and Technology (Campinas), 34(3), 566-570. http://dx.doi.org/10.1590/1678457x.6373.

Cho, Y. R., Chang, J. Y., \& Chang, H. C. (2007). Production of $\gamma$-aminobutyric acid (GABA) by Lactobacillus buchneri isolated from kimchi and its neuroprotective effect on neuronal cells. Journal of Microbiology and Biotechnology, 17(1), 104-109. PMid:18051360.

Cotter, P. D., Gahan, C. G. M., \& Hill, C. (2001). A glutamate decarboxylase system protects Listeria monocytogenes in gastric fluid. Molecular Microbiology, 40(2), 465-475. http://dx.doi. org/10.1046/j.1365-2958.2001.02398.x. PMid:11309128
Food and Agricultural Organization - FAO \& World Health Organization - WHO. (1987). Evaluation of certain food additives and contaminants: thirtieth report of the joint FAO/WHO expert committee on food additives (pp. 15-16, World Health Organization Technical Report Series, 751). Geneva.

Foster, J. W. (2001). Acid stress responses of Salmonella and E. coli: survival mechanisms, regulation, and implications for pathogenesis. Journal of Microbiology (Seoul, Korea), 39(2), 89-94.

Fraga Cotelo, M., Perelmuter Schein, K., Giacaman Salvo, S. S., Zunino Abirad, P. M., \& Carro Techera, S. B. (2013). Antimicrobial properties of lactic acid bacteria isolated from Uruguayan artisan cheese. Food Science and Technology (Campinas), 33(4), 801-804. http://dx.doi.org/10.1590/S0101-20612013000400029.

Hiraga, K., Ueno, Y., \& Oda, K. (2008). Glutamate decarboxylase from Lactobacillus brevis: activation by ammonium sulfate. Bioscience, Biotechnology, and Biochemistry, 72(5), 1299-1306. http://dx.doi. org/10.1271/bbb.70782. PMid:18460820

Jeon, J. M., Lee, H. I., \& So, J. S. (2009). Glutaminase activity of Lactobacillus reuteri KCTC3594 and expression of the activity in other Lactobacillus spp. by introduction of the glutaminase gene. African Journal of Microbiological Research, 3(10), 605-609.

Katikala, P. K., Bobbarala, V., Tadimalla, P., \& Guntuku, G. S. (2009). Screening of L-glutaminase producing marine bacterial cultures for extracellular production of L-glutaminase. International Journal of ChemTech Research, 1(4), 1232-1235.

Kato, Y., Kato, Y., Furukawa, K., \& Hara, S. (2002). Cloning and nucleotide sequence of the glutamate decarboxylase-encoding gene gadA from Aspergillus oryzae. Bioscience, Biotechnology, and Biochemistry, 66(12), 2600-2605. http://dx.doi.org/10.1271/ bbb.66.2600. PMid:12596854

Kennedy, S. P., Ng, W. V., Salzberg, S. L., Hood, L., \& DasSarma, S. (2001). Understanding the adaptation of Halobacterium species NRC-1 to its extreme environment through computational analysis of its genome sequence. Genome Research, 11(10), 1641-1650. http:// dx.doi.org/10.1101/gr.190201. PMid:11591641

Kieronczyk, A., Skeie, S., Olsen, K., \& Langsrud, T. (2001). Metabolism of amino acids by resting cells of non-starter lactobacilli in relation to flavour development in cheese. International Dairy Journal, 11(47), 217-224. http://dx.doi.org/10.1016/S0958-6946(01)00051-6.

Kim, O. S., Cho, Y. J., Lee, K., Yoon, S. H., Kim, M., Na, H., Park, S. C., Jeon, Y. S., Lee, J. H., Yi, H., Won, S., \& Chun, J. (2012). Introducing EzTaxon-e: a prokaryotic $16 \mathrm{~S}$ rRNA gene sequence database with phylotypes that represent uncultured species. International Journal of Systematic and Evolutionary Microbiology, 62(Pt 3), 716-721. http://dx.doi.org/10.1099/ijs.0.038075-0. PMid:22140171

Koibuchi, K., Nagasaki, H., Yuasa, A., Kataoka, J., \& Kitamoto, K. (2000). Molecular cloning and characterization of a gene encoding glutaminase from Aspergillus oryzae. Applied Microbiology and Biotechnology, 54(1), 59-68. http://dx.doi.org/10.1007/ s002530000329. PMid:10952006

Komatsuzaki, N., Nakamura, T., Kimura, T., \& Shima, J. (2008). Characterization of glutamate decarboxylase from a high gammaaminobutyric acid (GABA)-producer, Lactobacillus paracasei. Bioscience, Biotechnology, and Biochemistry, 72(2), 278-285. http:// dx.doi.org/10.1271/bbb.70163. PMid:18256502

Komatsuzaki, N., Shima, J., Kawamoto, S., Momose, H., \& Kimura, T. (2005). Production of $\gamma$-aminobutyric acid (GABA) by Lactobacillus paracasei isolated from traditional fermented foods. Food Microbiology, 22(6), 497-504. http://dx.doi.org/10.1016/j. fm.2005.01.002. 
Krnjević, K. (1974). Chemical nature of synaptic transmission in vertebrates. Physiological Reviews, 54(2), 418-540.

Leroy, F., Verluyten, J., \& De Vuyst, L. (2006). Functional meat starter cultures for improved sausage fermentation. International Journal of Food Microbiology, 106(3), 270-285. http://dx.doi.org/10.1016/j. ijfoodmicro.2005.06.027. PMid:16213053

Lin, J., Lee, I. S., Frey, J., Slonczewski, J. L., \& Foster, J. W. (1995). Comparative analysis of extreme acid survival in Salmonella typhimurium, Shigella flexneri, and Escherichia coli. Journal of Bacteriology, 177(14), 4097-4104. PMid:7608084.

Lu, X., Xie, C., \& Gu, Z. (2009). Optimisation of fermentative parameters for GABA enrichment by Lactococcus lactis. Czech Journal of Food Sciences, 27, 433-442.

Madern, D., Ebel, C., \& Zaccai, G. (2000). Halophilic adaptation of enzymes. Extremophiles, 4(2), 91-98. http://dx.doi.org/10.1007/ s007920050142. PMid:10805563

Moriguchi, M., Sakai, K., Tateyama, R., Furuta, Y., \& Wakayama, M. (1994). Isolation and characterization of salt-tolerant glutaminases from marine Micrococcus luteus K-3. Journal of Fermentation and Bioengineering, 77(6), 621-625. http://dx.doi.org/10.1016/0922338X(94)90143-0.

Nandakumar, R., Yoshimune, K., Wakayama, M., \& Moriguchi, M. (2003). Microbial glutaminase: biochemistry, molecular approaches and applications in the food industry. Journal of Molecular Catalysis. B, Enzymatic, 23(2-6), 87-100. http://dx.doi.org/10.1016/ S1381-1177(03)00075-4.

Olier, M., Rousseaux, S., Piveteau, P., Lemaître, J.-P., Rousset, A., \& Guzzo, J. (2004). Screening of glutamate decarboxylase activity and bile salt resistance of human asymptomatic carriage, clinical, food, and environmental isolates of Listeria monocytogenes. International Journal of Food Microbiology, 93(1), 87-99. http:// dx.doi.org/10.1016/j.ijfoodmicro.2003.10.010. PMid:15135585

Park, K. B., \& Oh, S. H. (2006). Isolation and characterization of Lactobacillus buchneri strains with high gamma-aminobutyric acid producing capacity from naturally aged cheese. Food Science and Biotechnology, 15, 86-90.

Park, K.B., \& Oh, S.H. (2007). Cloning, sequencing and expression of a novel glutamate decarboxylase gene from a newly isolated lactic acid bacterium, Lactobacillus brevis OPK-3. Bioresource Technology, 98(2), 312-319. http://dx.doi.org/10.1016/j.biortech.2006.01.004. PMid: 16500100

Pérez-Chabela, M. L., Totosaus, A., \& Guerrero, I. (2008). Evaluation of thermotolerant capacityof lactic acid bacteria isolated from commercial sausages and the effects of their addition on the quality of cooked sausages. Ciência e Tecnologia de Alimentos, 28(1), 132138. http://dx.doi.org/10.1590/S0101-20612008000100019.

Prusiner, S., Davis, J. N., \& Stadtman, E. R. (1976). Regulation of glutaminase B in Escherichia coli. I. Purification, properties, and cold lability. The Journal of Biological Chemistry, 251(11), 34473456. PMid:6454.

Ratanaburee, A., Kantachote, D., Charernjiratrakul, W., Penjamras, P., \& Chaiyasut, C. (2011). Enhancement of $\gamma$-aminobutyric acid in a fermented red seaweed beverage by starter culture Lactobacillus plantarum DW12. Electronic Journal of Biotechnology, 14(3), 1-14.

Sambrook, J., \& Russell, D. W. (2001). Molecular cloning: A laboratory manual (3rd ed.). New York: Cold Spring Harbor Laboratory Press.

Sanders, J. W., Leenhouts, K., Burghoorn, J., Brands, J. R., Venema, G., \& Kok, J. (1998). A chloride-inducible acid resistance mechanism in Lactococcus lactis and its regulation. Molecular Microbiology, 27(2), 299-310. http://dx.doi.org/10.1046/j.1365-2958.1998.00676.x. PMid:9484886
Shimada, M., Hasegawa, T., Nishimura, C., Kan, H., Kanno, T., Nakamura, T., \& Matsubayashi, T. (2009). Anti-hypertensive effect of gamma-aminobutyric acid (GABA)-rich Chlorella on high-normal blood pressure and borderline hypertension in placebo-controlled double blind study. Clinical and Experimental Hypertension, 31(4), 342-354. http://dx.doi.org/10.1080/10641960902977908. PMid:19811362

Siragusa, S., De Angelis, M., Di Cagno, R., Rizzello, C. G., Coda, R., \& Gobbetti, M. (2007). Synthesis of $\gamma$-aminobutyric acid by lactic acid bacteria isolated from a variety of Italian cheeses. Applied and Environmental Microbiology, 73(22), 7283-7290. http://dx.doi. org/10.1128/AEM.01064-07. PMid:17890341

Sivakumar, K., Sahu, M. K., Manivel, P. R., \& Kannan, L. (2006). Optimum conditions for L-glutaminase production by actinomycete strain isolated from estuarine fish, Chanos chanos (Forskal, 1775). Indian Journal of Experimental Biology, 44(3), 256-258. PMid:16538868.

Soltani, N., Qiu, H., Aleksic, M., Glinka, Y., Zhao, F., Liu, R., Li, Y., Zhang, N., Chakrabarti, R., Ng, T., Jin, T., Zhang, H., Lu, W. Y., Feng, Z. P., Prud'homme, G. J., \& Wang, Q. (2011). GABA exerts protective and regenerative effects on islet beta cells and reverses diabetes. PNAS Early Edition, 108(28), 11692-11697. PMid:21709230.

Su, M. S., Schlicht, S., \& Gänzle, M. G. (2011). Contribution of glutamate decarboxylase in Lactobacillus reuteri to acid resistance and persistence in sourdough fermentation. Microbial Cell Factories, 10(Suppl 1), S8. http://dx.doi.org/10.1186/1475-2859-10-S1-S8. PMid:21995488

Thongsanit, J., Tanikawa, M., Yano, S., Tpachiki, T., \& Wakayam, M. (2009). Identification of glutaminase-producing lactic acid bacteria isolated from Nham, a traditional Thai fermented food and characterisation of glutaminase activity of isolated Weissella cibaria. Annals of Microbiology, 59(4), 715-720. http://dx.doi.org/10.1007/ BF03179213.

Weingand-Ziadé, A., Gerber-Décombaz, C., \& Affolter, M. (2003). Functional characterization of a salt- and thermotolerant glutaminase from Lactobacillus rhamnosus. Enzyme and Microbial Technology, 32(7), 862-867. http://dx.doi.org/10.1016/S01410229(03)00059-0.

Yang, S. Y., Lin, Q., Lu, Z. X., Lu, F. X., Bie, X. M., Zou, X. K., \& Sun, L. J. (2008a). Characterization of a novel glutamate decarboxylase from Streptococcus salivarius ssp. thermophilus Y2. Journal of Chemical Technology and Biotechnology (Oxford, Oxfordshire), 83(6), 855-861. http://dx.doi.org/10.1002/jctb.1880.

Yang, S. Y., Lü, F. X., Lu, Z. X., Bie, X. M., Jiao, Y., Sun, L. J., \& Yu, B. (2008b). Production of gamma-aminobutyric acid by Streptococcus salivarius subsp. thermophilus Y2 under submerged fermentation. Amino Acids, 34(3), 473-478. http://dx.doi.org/10.1007/s00726007-0544-x. PMid:17514494

Yano, T., Ito, M., Tomita, K., \& Kumagai, H. (1988). Purification and properties of glutaminase from Aspergillus oryzae. Journal of Fermentation Technology, 66(2), 137-143. http://dx.doi. org/10.1016/0385-6380(88)90039-8.

Yokoyama, S., Hiramatsu, J., \& Hayakawa, K. (2002). Production of gamma-aminobutyric acid from alcohol distillery lees by Lactobacillus brevis IFO-12005. Journal of Bioscience and Bioengineering, 93(1), 95-97. http://dx.doi.org/10.1016/S13891723(02)80061-5. PMid:16233172

Yerlikaya, O. (2014). Starter cultures used in probiotic dairy product preparation and popular probiotic dairy drinks. Food Science and Technology (Campinas), 34(2), 221-229. http://dx.doi.org/10.1590/ fst.2014.0050. 
Supplementary Table 1. Details of LAB and positives for glutaminase and GAD production isolated from fermented foods.

\begin{tabular}{|l|l|l|l|l|}
\hline Samples & $\begin{array}{l}\text { No. of } \\
\text { Samples }\end{array}$ & $\begin{array}{l}\text { No. of LAB } \\
\text { isolates }\end{array}$ & $\begin{array}{l}\text { Positive for } \\
\text { Glutaminase }\end{array}$ & $\begin{array}{l}\text { Positive for } \\
\text { GAD }\end{array}$ \\
\hline Fermented fruit & 16 & 51 & 1 & 38 \\
\hline Fermented vegetable & 24 & 119 & 10 & 88 \\
\hline Soy paste & 9 & 40 & 2 & 31 \\
\hline Shrimp paste & 5 & 21 & 3 & 9 \\
\hline Fermented fish & 11 & 55 & 5 & 31 \\
\hline Fermented crab & 3 & 21 & - & 14 \\
\hline Fermented pork and meat & 4 & 31 & 1 & 26 \\
\hline Total & $\mathbf{7 2}$ & $\mathbf{3 3 8}$ & $\mathbf{2 2}$ & $\mathbf{2 3 7}$ \\
\hline
\end{tabular}


Supplementary Table 2. Impact of temperature and $\mathrm{pH}$ on glutaminase production. Values are representative of mean \pm SD of three independent experiments (ND: Not detected).

\begin{tabular}{|c|c|c|c|c|c|c|c|c|c|c|}
\hline \multirow{4}{*}{ Strains } & \multirow{4}{*}{ Days } & \multicolumn{9}{|c|}{ Glutaminase production (U/mg protein) } \\
\hline & & \multicolumn{9}{|c|}{ Temperature } \\
\hline & & \multicolumn{3}{|c|}{$30^{\circ} \mathrm{C}$} & \multicolumn{3}{|c|}{$35^{\circ} \mathrm{C}$} & \multicolumn{3}{|c|}{$40^{\circ} \mathrm{C}$} \\
\hline & & pH6.0 & $\mathrm{pH} 7.0$ & $\mathrm{pH} 8.0$ & pH6.0 & $\mathrm{pH} 7.0$ & $\mathrm{pH} 8.0$ & pH6.0 & $\mathrm{pH} 7.0$ & $\mathrm{pH} 8.0$ \\
\hline G284/2 & 0 & ND & ND & ND & ND & ND & ND & ND & ND & ND \\
\hline G507/1 & 0 & ND & ND & ND & ND & ND & ND & ND & ND & ND \\
\hline G284/2 & 2 & $0.09 \pm 0$ & $0.21 \pm 0.10$ & ND & $1.14 \pm 0.10$ & ND & ND & ND & $0.07 \pm 0.00$ & ND \\
\hline G507/1 & 2 & $\mathrm{ND}$ & ND & ND & $0.54 \pm 0.10$ & ND & ND & ND & ND & ND \\
\hline G284/2 & 4 & $0.20 \pm 0.02$ & $0.22 \pm 0.10$ & ND & $1.08 \pm 0.20$ & $0.23 \pm 0.10$ & ND & ND & $0.09 \pm 0.01$ & ND \\
\hline G507/1 & 4 & $0.02 \pm 0$ & ND & ND & $1.95 \pm 0.40$ & $0.00 \pm 0.00$ & $\mathrm{ND}$ & ND & $0.09 \pm 0.00$ & ND \\
\hline G284/2 & 6 & $0.24 \pm 0.04$ & $0.24 \pm 0.10$ & ND & $1.37 \pm 0.30$ & $0.37 \pm 0.10$ & ND & ND & $0.17 \pm 0.01$ & ND \\
\hline G507/1 & 6 & $0.07 \pm 0$ & ND & ND & $1.37 \pm 0.30$ & $0.00 \pm 0.00$ & ND & $0.10 \pm 0.00$ & $0.13 \pm 0.01$ & ND \\
\hline G284/2 & 8 & $0.30 \pm 0.05$ & $0.29 \pm 0.10$ & ND & $2.31 \pm 0.30$ & $0.64 \pm 0.10$ & ND & ND & $0.24 \pm 0.02$ & ND \\
\hline G507/1 & 8 & $0.26 \pm 0.10$ & $0.02 \pm 0.00$ & ND & $2.95 \pm 0.40$ & $0.96 \pm 0.30$ & $1.68 \pm 0.30$ & $0.40 \pm 0.02$ & $0.21 \pm 0.03$ & ND \\
\hline G284/2 & 10 & $0.32 \pm 0.03$ & $0.31 \pm 0.10$ & ND & $2.51 \pm 0.30$ & $0.59 \pm 0.10$ & $0.35 \pm 0.10$ & ND & $0.25 \pm 0.04$ & ND \\
\hline G507/1 & 10 & $0.34 \pm 0.10$ & $0.10 \pm 0.02$ & ND & $3.38 \pm 0.30$ & $1.29 \pm 0.20$ & $2.75 \pm 0.20$ & $0.47 \pm 0.10$ & $0.31 \pm 0.01$ & ND \\
\hline G284/2 & 12 & $0.43 \pm 0.20$ & $0.50 \pm 0.10$ & ND & $2.48 \pm 0.40$ & $2.21 \pm 0.20$ & $0.53 \pm 0.20$ & $0.09 \pm 0.00$ & $0.23 \pm 0.10$ & ND \\
\hline G507/1 & 12 & $0.45 \pm 0.10$ & $0.15 \pm 0.05$ & $0.02 \pm 0$ & $4.21 \pm 0.20$ & $1.73 \pm 0.30$ & $2.28 \pm 0.20$ & $0.63 \pm 0.07$ & $0.30 \pm 0.01$ & ND \\
\hline G284/2 & 14 & $0.56 \pm 0.10$ & $0.59 \pm 0.10$ & $0.04 \pm 0$ & $3.04 \pm 0.30$ & $2.07 \pm 0.20$ & $0.93 \pm 0.20$ & $0.19 \pm 0.01$ & $0.30 \pm 0.10$ & ND \\
\hline G507/1 & 14 & $0.45 \pm 0.20$ & $0.20 \pm 0.10$ & $0.19 \pm 0.04$ & $5.59 \pm 0.50$ & $2.37 \pm 0.30$ & $3.84 \pm 0.80$ & $0.60 \pm 0.03$ & $0.42 \pm 0.10$ & ND \\
\hline G284/2 & 16 & $0.57 \pm 0.20$ & $0.75 \pm 0.20$ & $0.18 \pm 0.10$ & $3.64 \pm 0.30$ & $2.61 \pm 0.30$ & $1.59 \pm 0.30$ & $0.26 \pm 0.02$ & $0.43 \pm 0.10$ & ND \\
\hline G507/1 & 16 & $0.73 \pm 0.10$ & $0.25 \pm 0.10$ & $0.30 \pm 0.10$ & $6.09 \pm 0.50$ & $2.88 \pm 0.40$ & $3.95 \pm 0.40$ & $0.82 \pm 0.10$ & $0.50 \pm 0.10$ & ND \\
\hline G284/2 & 18 & $0.60 \pm 0.10$ & $0.75 \pm 0.20$ & $0.41 \pm 0.20$ & $4.40 \pm 0.40$ & $4.05 \pm 0.50$ & $3.40 \pm 0.40$ & $0.36 \pm 0.06$ & $0.39 \pm 0.10$ & ND \\
\hline G507/1 & 18 & $0.96 \pm 0.10$ & $0.38 \pm 0.10$ & $0.51 \pm 0.20$ & $6.81 \pm 0.80$ & $3.62 \pm 0.30$ & $4.26 \pm 0.20$ & $1.11 \pm 0.10$ & $0.71 \pm 0.10$ & $0.04 \pm 0.00$ \\
\hline G284/2 & 20 & $0.99 \pm 0.10$ & $1.11 \pm 0.10$ & $0.87 \pm 0.10$ & $4.70 \pm 0.70$ & $5.06 \pm 0.50$ & $3.56 \pm 0.50$ & $0.50 \pm 0.10$ & $0.81 \pm 0.10$ & ND \\
\hline G507/1 & 20 & $1.52 \pm 0.10$ & $0.41 \pm 0.10$ & $0.96 \pm 0.10$ & $7.39 \pm 1.00$ & $4.92 \pm 0.40$ & $5.29 \pm 0.50$ & $1.28 \pm 0.10$ & $0.86 \pm 0.10$ & $0.16 \pm 0.03$ \\
\hline G284/2 & 30 & $1.11 \pm 0.10$ & $1.24 \pm 0.10$ & $0.61 \pm 0.10$ & $4.55 \pm 0.50$ & $4.92 \pm 0.40$ & $3.53 \pm 0.50$ & $0.73 \pm 0.10$ & $0.87 \pm 0.10$ & ND \\
\hline G507/1 & 30 & $1.35 \pm 0.10$ & $0.61 \pm 0.10$ & $1.16 \pm 0.10$ & $7.46 \pm 0.40$ & $4.63 \pm 0.30$ & $4.91 \pm 0.50$ & $1.27 \pm 0.10$ & $0.96 \pm 0.10$ & $0.48 \pm 0.10$ \\
\hline
\end{tabular}


Supplementary Table 3. GABA production by LABs at different temperature and $\mathrm{pH}$ (ND: Not detected).

\begin{tabular}{|c|c|c|c|c|c|c|c|c|c|c|}
\hline \multirow{4}{*}{ Strains } & \multirow{4}{*}{ Days } & \multicolumn{9}{|c|}{ GABA production $(\mathrm{mg} / \mathrm{ml})$} \\
\hline & & \multicolumn{9}{|c|}{ Temperature } \\
\hline & & \multicolumn{3}{|c|}{$30^{\circ} \mathrm{C}$} & \multicolumn{3}{|c|}{$35^{\circ} \mathrm{C}$} & \multicolumn{3}{|c|}{$40^{\circ} \mathrm{C}$} \\
\hline & & $\mathrm{pH} 4.5$ & pH5.5 & pH6.5 & $\mathrm{pH} 4.5$ & pH5.5 & pH6.5 & $\mathrm{pH} 4.5$ & pH5.5 & pH6.5 \\
\hline G30/1 & 0 & $0.23 \pm 0.10$ & $0.38 \pm 0.20$ & $0.36 \pm 0.10$ & ND & $0.09 \pm 0.01$ & $0.25 \pm 0.10$ & ND & ND & $0.25 \pm 0.10$ \\
\hline $\mathrm{G} 254 / 2$ & 0 & $0.33 \pm 0.10$ & $0.49 \pm 0.20$ & $0.39 \pm 0.10$ & $0.20 \pm 0.01$ & $0.49 \pm 0.20$ & $0.25 \pm 0.10$ & $0.34 \pm 0.10$ & $0.30 \pm 0.10$ & $0.25 \pm 0.10$ \\
\hline G30/1 & 5 & $0.90 \pm 0.10$ & $1.89 \pm 0.20$ & $1.39 \pm 0.10$ & $2.26 \pm 0.20$ & $0.52 \pm 0.20$ & $0.37 \pm 0.10$ & $0.47 \pm 0.10$ & $0.43 \pm 0.10$ & $0.38 \pm 0.10$ \\
\hline $\mathrm{G} 254 / 2$ & 5 & $1.48 \pm 0.20$ & $1.74 \pm 0.10$ & $2.62 \pm 0.10$ & $0.76 \pm 0.10$ & $7.59 \pm 1.00$ & $7.51 \pm 0.50$ & $0.49 \pm 0.10$ & $0.70 \pm 0.20$ & $1.29 \pm 0.20$ \\
\hline G30/1 & 10 & $1.03 \pm 0.10$ & $1.72 \pm 0.20$ & $1.57 \pm 0.10$ & $3 \pm 0.50$ & $0.83 \pm 0.10$ & $0.51 \pm 0.10$ & $0.53 \pm 0.10$ & $0.65 \pm 0.10$ & $0.47 \pm 0.10$ \\
\hline G254/2 & 10 & $1.31 \pm 0.10$ & $1.43 \pm 0.20$ & $2.53 \pm 0.10$ & $8.17 \pm 0.10$ & $9.24 \pm 0.20$ & $8.74 \pm 0.50$ & $1.48 \pm 0.20$ & $5.03 \pm 1.00$ & $12.73 \pm 1.0$ \\
\hline G30/1 & 15 & $1.19 \pm 0.10$ & $1.61 \pm 0.20$ & $1.66 \pm 0.10$ & $8.96 \pm 0.30$ & $0.86 \pm 0.20$ & $0.50 \pm 0.10$ & $0.55 \pm 0.10$ & $0.66 \pm 0.10$ & $0.42 \pm 0.10$ \\
\hline G254/2 & 15 & $1.22 \pm 0.20$ & $1.58 \pm 0.20$ & $2.30 \pm 0.10$ & $8.17 \pm 0.30$ & $9.35 \pm 0.30$ & $8.76 \pm 0.20$ & $1.48 \pm 0.20$ & $5.44 \pm 1.00$ & $12.53 \pm 1.0$ \\
\hline G30/1 & 20 & $1.30 \pm 0.20$ & $1.49 \pm 0.20$ & $2.32 \pm 0.20$ & $8.94 \pm 0.50$ & $0.90 \pm 0.10$ & $0.61 \pm 0.10$ & $0.56 \pm 0.10$ & $0.68 \pm 0.10$ & $0.46 \pm 0.10$ \\
\hline G254/2 & 20 & $1.13 \pm 0.10$ & $1.44 \pm 0.20$ & $2.40 \pm 0.05$ & $8.21 \pm 0.10$ & $9.38 \pm 0.30$ & $8.82 \pm 0.30$ & $1.52 \pm 0.30$ & $5.90 \pm 1.00$ & $12.69 \pm 1.0$ \\
\hline G30/1 & 30 & $1.36 \pm 0.30$ & $1.51 \pm 0.10$ & $2.18 \pm 0.10$ & $8.96 \pm 0.50$ & $0.87 \pm 0.20$ & $0.58 \pm 0.10$ & $0.55 \pm 0.10$ & $0.65 \pm 0.10$ & $0.41 \pm 0.20$ \\
\hline G254/2 & 30 & $1.07 \pm 0.10$ & $1.45 \pm 0.20$ & $2.34 \pm 0.04$ & $8.18 \pm 0.20$ & $9.34 \pm 0.30$ & $8.77 \pm 0.30$ & $1.48 \pm 0.20$ & $5.65 \pm 1.00$ & $12.54 \pm 1.0$ \\
\hline
\end{tabular}


Supplementary Table 4. Residual glutamic acid content at different temperature and $\mathrm{pH}$. Values are represented as mean \pm SD of three experiments. (ND: Not detected).

\begin{tabular}{|c|c|c|c|c|c|c|c|c|}
\hline \multicolumn{9}{|c|}{ Residual glutamic acid $(\mathrm{mg} / \mathrm{ml})$} \\
\hline \multicolumn{9}{|c|}{ Temperature } \\
\hline \multicolumn{3}{|c|}{$30^{\circ} \mathrm{C}$} & \multicolumn{3}{|c|}{$35^{\circ} \mathrm{C}$} & \multicolumn{3}{|c|}{$40^{\circ} \mathrm{C}$} \\
\hline $\mathrm{pH} 4.5$ & $\mathrm{pH} 5.5$ & $\mathrm{pH} 6.5$ & $\mathrm{pH} 4.5$ & $\mathrm{pH} 5.5$ & pH6.5 & $\mathrm{pH} 4.5$ & pH5.5 & pH6.5 \\
\hline $9.06 \pm 1.00$ & $9.67 \pm 1.00$ & $10.53 \pm 1.00$ & $29.98 \pm 1.0$ & $20.23 \pm 2$ & $10.74 \pm 1$ & $29.26 \pm 1.0$ & $16.70 \pm 2$ & $17.06 \pm 2$ \\
\hline $8.15 \pm 1.00$ & $8.85 \pm 1.00$ & $16.72 \pm 1.00$ & $34.10 \pm 2.0$ & $19.63 \pm 2$ & $8.86 \pm 2$ & $30.27 \pm 2.0$ & $16.13 \pm 2$ & $15.76 \pm 1$ \\
\hline $0.15 \pm 0.02$ & $0.03 \pm 0.004$ & $0.03 \pm 0.001$ & $16.66 \pm 2.0$ & $12.49 \pm 2$ & $7.83 \pm 0.8$ & $23.93 \pm 1.0$ & $8.37 \pm 1$ & $10.26 \pm 1$ \\
\hline $0.34 \pm 0.03$ & $0.03 \pm 0.001$ & $0.03 \pm 0.002$ & $23.52 \pm 1.0$ & $0.37 \pm 0.1$ & ND & $24.29 \pm 2.0$ & $8.77 \pm 2$ & $10.07 \pm 2$ \\
\hline $0.10 \pm 0.01$ & $0.03 \pm 0.002$ & $0.03 \pm 0.002$ & $2.09 \pm 0.15$ & $12.27 \pm 1$ & $6.91 \pm 1$ & $23.14 \pm 2.0$ & $6.29 \pm 1$ & $6.34 \pm 1$ \\
\hline $0.03 \pm 0.001$ & $0.03 \pm 0.003$ & $0.03 \pm 0.003$ & $6.57 \pm 0.50$ & $0.25 \pm 0.1$ & ND & $21.29 \pm 2.0$ & $5.03 \pm 2$ & $0.05 \pm 0.02$ \\
\hline $0.03 \pm 0.01$ & $0.03 \pm 0.003$ & $0.03 \pm 0.004$ & $1.98 \pm 0.1$ & $12.18 \pm 1$ & $6.70 \pm 1$ & $22.92 \pm 1.0$ & $6.07 \pm 1$ & $6.26 \pm 1$ \\
\hline $0.03 \pm 0.001$ & $0.03 \pm 0.002$ & $0.03 \pm 0.004$ & $6.46 \pm 0.04$ & $0.24 \pm 0.1$ & ND & $19.75 \pm 2.0$ & $4.76 \pm 2$ & $0.03 \pm 0.01$ \\
\hline $0.03 \pm 0.01$ & $0.03 \pm 0.003$ & $0.03 \pm 0.002$ & $1.95 \pm 0.1$ & $11.91 \pm 2$ & $6.38 \pm 1$ & $22.60 \pm 2.0$ & $5.83 \pm 1$ & $6.13 \pm 1$ \\
\hline $0.29 \pm 0.04$ & $0.01 \pm 0.001$ & $0.03 \pm 0.004$ & $6.35 \pm 0.3$ & $0.23 \pm 0.1$ & ND & $18.66 \pm 2.0$ & $4.46 \pm 2$ & $0.04 \pm 0.01$ \\
\hline $0.03 \pm 0.01$ & $0.03 \pm 0.002$ & $0.03 \pm 0.004$ & $1.92 \pm 0.45$ & $12.06 \pm 2$ & $6.18 \pm 1$ & $22.71 \pm 2.0$ & $5.71 \pm 1$ & $5.57 \pm 1$ \\
\hline $0.03 \pm 0.002$ & $0.03 \pm 0.004$ & $0.03 \pm 0.004$ & $6.57 \pm 0.5$ & $0.22 \pm 0.1$ & ND & $17.64 \pm 2.0$ & $4.46 \pm 2$ & $0.02 \pm 0.01$ \\
\hline
\end{tabular}

